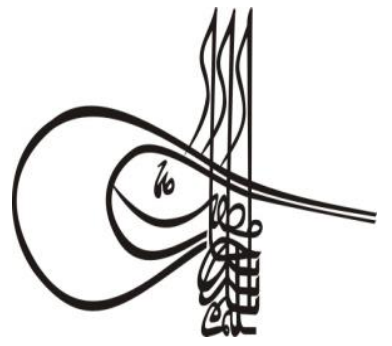

Received/Geliş: 09.08.2019

\section{Turkists Studies Educational Sciences}

Volume 14 Issue 5, 2019, p. 2581-2600

DOI: 10.29228/TurkishStudies.30198

ISSN: 2667-5609

Skopje/MACEDONIA-Ankara/TURKEY

Research Article / Araştırma Makalesi

Article Info/Makale Bilgisi

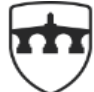

INTERNATIONAL BALKAN UNIVERSITY

EXCELLENCE FOR THE FUTUR IBU.EDU.MK

Gor Report Dates/Rapor Tarihleri: Referee 1 (22.08.2019)-Referee 2 (23.08.2019)

This article was checked by iThenticate.

\title{
LİSE SIYYASİ COĞRAFYA KONULARINDA ÖĞRENCİ BAŞARILARINA YÖNELİK ÖĞRETMEN GÖRÜŞLERİ
}

\author{
Saim ÖZTOPAL $L^{* *}-$ Necati TOMAL $L^{* * *}$
}

öz

Siyasi coğrafya, coğrafya biliminin alt dalı olan beşerî coğrafya altında yer alan bir disiplindir. Bu disiplin, ülkelerin politikasında ve dünya siyasetinde coğrafi özelliklerin etkisini araştırır. Dünyada ve komşu ülkelerde olup bitenleri takip eden gençlerin bulunduğu güçlü bir Türkiye için tüm eğitim kademelerinde siyasi coğrafya konularının öğretimi önemlidir. Bu çalışmada liselerdeki siyasi coğrafya konularının öğretiminde öğrenci başarıları ve başarı üzerinde etkili olan faktörler öğretmen görüşleri doğrultusunda değerlendirilmeye çalışılmıştır. Lise kademesinde siyasi coğrafya konularının öğretimi ile ilgili çalışmalar azdır. Bu durum çalışmamızın önemini artırmaktadır.

Araştırmada çalışma grubunu Giresun ilinde görev yapan cinsiyetleri, kıdemleri ve görev yaptıkları okul türleri farklı 20 öğretmen olușturmaktadır. Çalıșmada nitel araștırmada veri toplama tekniği olan yarı yapılandırılmış görüşme uygulanmıştır. Sorulara verilen cevapların analizinde içerik analizi tekniği kullanılmıştır. Çalışmada öğretmen görüşlerine göre; siyasi coğrafya konularında öğrenci başarıları genelde iyidir. Türkiye'nin jeopolitik konumu ve dünyadaki sıcak çatışma bölgeleri konularındaki başarıları, bölgesel ve küresel örgütler ile Türkiye'nin çevresindeki bölgesel sorunlar konularına göre daha iyidir. Bazı konularda öğrencilerin daha başarılı bazılarında ise daha az başarılı olmalarında çok çeşitli faktörler etkilidir. Bu çalışmada bunlar ortaya koyulmaya çalışılmıştır. Siyasi coğrafya konularında öğrenci başarılarının artması için yapılabilecek pek çok şey vardır. Konularla

\footnotetext{
*Bu çalışmanın hazırlanmasında "Lise Coğrafya Dersi Öğretim Programındaki Siyasi Coğrafya Konularına İlişkin Öğrenci Başarılarının ve Tutumlarının Değerlendirilmesi” isimli yüksek lisans tezinden yararlanılmııstır.

Öğretmen. Keşap Şehit İsmail Kefal Anadolu İmam Hatip Lisesi, E-posta: s.oztopal@hotmail.com

Doç. Dr. Ondokuz Mayıs Üniversitesi Eğitim Fakültesi, E-posta: ntomal@ omu.edu.tr
} 
ilişkili gazete ve dergi haberlerini kullanmak ve yoğun bilgiden ziyade yaşamla ilişkili bilgilere öğretimde ağırlık vermek bunların bazılarıdır.

Anahtar Kelimeler: Siyasi coğrafya, coğrafya öğretimi, lise öğretimi

\title{
TEACHERS' OPINIONS TOWARDS STUDENT SUCCESS IN HIGH SCHOOL POLITICAL GEOGRAPHY SUBJECTS
}

\begin{abstract}
Political geography is a sub-discipline of anthropogeography which is a sub-discipline of geography itself. This discipline examines the effects of geographical characteristics on national policies and international politics. Teaching of political geography in all stages of education is necessary for a strong Turkey with young people who follow the developments in the world and neighbouring countries. This study endeavours to evaluate student success in and factors affecting political geography subjects in high school education based on opinions of the teachers. The number of studies on teaching of political geography subjects on high school level is very small. This situation increases the importance of this study.

In this study the work group comprises of 20 teachers from various genders, seniorities and school types, all employed in Giresun Province. Semi-structured interview technique, a qualitative data collection technique, was utilised in this study. Content analysis technique was used to analyse the responses to the questions. According to study results student success in political geography subjects is generally good. Student success in subjects of geopolitical position of Turkey and regional problem it faces is better in comparison to student success in subjects of regional and global organisations and hot conflict areas across the world. Many factors have effect on the students having more success in some subject while having less in some others. This study aims to reveal these factors. There are many actions that can be taken to increase student success in political geography. Some of these are using newspaper and magazine articles related to these subjects and focusing on life knowledge rather than intensive information in education.
\end{abstract}

\section{STRUCTURED ABSTRACT}

\section{Introduction}

Just as mathematics and philosophy, geography is also one of the oldest branches of science. Fields of study under this branch of science like climate and geographical formations can be considered in context of natural sciences, while fields of study like population, settlement and industry under the same can be considered in context of social sciences. As it can be understood, it is difficult to define this branch of science which provides an interdisciplinary and widespread field of study.

While having a diverse field of study, geography has two main sub-branches, namely physical and social geography. Political 
geography falls under social geography. Emergence of political geography as a modern discipline coincides with $19^{\text {th }}$ century. However, before the foundations of modern political geography were laid, many researchers have pointed out effects of geography on human life and politics. İbn-i Haldun's words "Geography is fate" and Herodotus' words "Egypt is a gift of the Nile" are the best examples of this concept. As pointed out by Özgen (2010:9) "natural environment has a significant effect in formation and disintegration of cultures of human societies." Ratzel, one of the advocates of deterministic view, is accepted as the founder of political geography. On the other hand, Deniz (2010:36) sees political geography as a discipline placed in the centre of social geography and also encompassing elements of physical and economic geography. Just like the case of geography itself, this discipline also can be defined in many ways.

Peoples who know both the world and their own country very well and are able to plan accordingly can have larger activity in both global and regional politics. Demirci (2005) points out this by saying "economic and political strength of today's countries in global political arena is related not only to their ability to exploit their mathematical and special positions to the maximum, but also to the depth of their knowledge regarding physical, social and cultural characteristics of world countries, and particularly their neighbours." Political geography education hold great importance for the students to obtain qualifications to analyse, explain and interpret distribution and reasons of political events around the world, areas of conflict, geopolitical characteristics of countries, and the power and activity level of countries. In conclusion, education in the science geography in general and the discipline of political geography in particular which we have considered in regard of its importance in raising young people aware of their country and the world are very important in every stage of education in our country. Due to this important, this study endeavours to analyse student success in political geography subjects in high school geography education programs in line with opinions of the teachers.

\section{Research Model}

Interviews were conducted with twenty geography teachers working in secondary education institutions attached to the Ministry of National Education in Giresun Province. The research consists of a qualitative study aiming to evaluate student success level in political geography subjects of the geography course according to opinions of the teachers.

"Qualitative research can be defined as research which uses data gathering methods like interviews and document analysis in order to exhibit perceptions and events in a realistic and holistic manner" (Yıldırım and Şimşek, 2013:45).

The pattern of this study consists of phenomenology, a type of qualitative research. According to Creswell (2007) phenomenology studies attempt to exhibit every participant's experiences related to a phenomenon. 
The study group of this research consists of 20 geography teachers working in secondary education institutions. Care was shown to select the subject teachers from different school. The "maximum diversity" sampling method was used to form the study group.

The content analysis technique is used to analyse the responses provided in the interviews. Content analysis requires detailed analysis of the collected data and helps reveal dimensions undiscovered thus far. In the study responses of the teachers were analysed to determine the factors affecting student success in the subject matter and it was attempted to determine frequencies of these factors.

\section{Findings, Discussion and Results}

According to geography teachers, the success level of students in political geography subjects is high in general. However, while the student success in subjects of geopolitical status of Turkey in historical process and hot conflict zones is higher, the success level in regard of regional problems in vicinity of Turkey, and global and regional organisation is lower.

According to opinions of the teachers, the factors affecting higher student success in regard of political geography subjects can be listed as follows:

a- Presence of regional problems directly or indirectly involving Turkey, geopolitical importance of Turkey and border contact between Turkey and modern conflict zones causes students to be more sensitive towards political geography subjects and increases their success level.

b- Another factor promoting success is political geography subjects being relevant to the daily life, frequently finding place in printed and visual media, in other words being current events.

c- Use of active learning methods and techniques in teaching of political geography subjects increases the level of success.

d- The fact that political geography subjects are also learned under the history course, especially the Modern Turkish and World History course in $12^{\text {th }}$ grade, has a large effect on higher student success level in this area.

e- One other factor affecting the level of success is the university exams. The student generally show more success in political geography subject which are highly likely to be question subjects in university selection exams.

f- Use of Google Earth program during lectures in political geography subjects increases the student success.

Factors that decrease success in some political geography subjects can be listed as follows:

a- $\quad$ Apathy of some students towards politics

b- $\quad$ Lack of map knowledge

c- Lack of knowledge on countries and lack of preparatory knowledge

d- Lack of critical and creative thinking abilities

Turkish Studies - Educational Sciences

Volume 14 Issue 5, 2019 
e- Larger interest in magazines, football, games, etc.

f- Students not being very satisfied with lectures using active learning methods

Keywords: Political geography, geography education, high school education.

\section{Giriș}

Coğrafya bilimi matematik, felsefe gibi en eski bilim dallarından biridir. Bu bilim dalının iklim, yerşekilleri gibi araştırma alanları fen bilimleri; nüfus, yerleşme, sanayi gibi araştırma alanları ise sosyal bilimler bağlamında düşünülebilir. Açıklamalardan da anlaşıldığı gibi disiplinler arası bir bilim dalı olan ve çalışma alanı da genişlik gösteren bu bilimin tanımını yapmak zordur.

Atalay (2001:1), coğrafya bilimini “yeryüzünün şekillenmesini, şekillenmede etkisi olan faktörleri ve yeryüzünün canlı hayatını oluşturan insan, bitki ve hayvan toplulukları ile doğal ortam arasındaki ilişkiyi inceleyen bilimdir" şeklinde tanımlamaktadır. Turoğlu (2003:52)'na göre; coğrafya ilmi "insan, mekân ve zaman elemanlarını birbiri ile ilişkilendiren, bu elemanlar ile ilgili tanımlama ve açıklamalar yapan, aralarındaki gelişmeleri sebep-sonuç ilişkilerini de kurarak değerlendirilmelerin yapılmasına imkân veren, çözüm önerileri sunma imkânına sahip uygulamalı bir bilim dalıdır" şeklinde açıklamıştır. Doğanay (1993:7) ise coğrafya bilimini "coğrafi yeryüzündeki doğal, beşerî ve ekonomik olayları insanla ilişki kurarak inceleyen bilim" olarak tanımlamaktadır. Kant coğrafya ile tarihi karşılaştırmış; coğrafyayı "mekânsal çeşitliliklerin incelenmesi" olarak tanımlamıştır (Tümertekin ve Özgüç, 1998:18). Eski bir bilim dalı ve interdisipliner bir bilim olması nedeni ile yukarıda da olduğu gibi coğrafya biliminin çok çeşitli tanımları yapılabilir. Yukarıda yapılan tanımları da dikkate alarak; coğrafya biliminin "doğal ve insan ürünü olan beşerî ortamları, bu ortamların insan ile ilişkisini de dikkate alarak neden-sonuç, dağılış ve bağlantı prensiplerine bağlı kalarak inceleyen bir bilim dalıdır" şeklinde tanımı yapılabilir.

Çok çeşitli inceleme alanı olan coğrafyanın fiziki ve beşerî coğrafya şeklinde iki ana alt dalı vardır. Siyasi coğrafya ise bu alt dallardan beşerî coğrafya altında yer alır. Siyasi coğrafyanın modern bir disiplin olarak ortaya çıkması 19. yüzyıla denk gelir. Ancak modern siyasi coğrafyanın temelleri atılmadan önce de pek çok araştırmacı coğrafyanın insan yaşamına ve siyasete etkisine dikkat çekmiştir. İbni Haldun'un "coğrafya kaderdir" ve Herodot'un "Misır Nil'in hediyesidir" sözleri bu duruma en güzel örneklerdir. Özgen (2010:9)'in de belirttiği gibi "insan topluluklarının kültürlerinin oluşmasında ve dağılışında büyük ölçüde doğal çevre etkilidir" determinist görüşünün savunucularından Ratzel siyasi coğrafyanın kurucusu olarak kabul edilmektedir. Deniz (2010:36) ise siyasi coğrafyayı beşerî coğrafyanın merkezinde yer alan ve aynı zamanda fiziki ve ekonomik coğrafya unsurlarını da kendi kapsamı içerisine alarak değerlendiren bir disiplin olarak görmüştür. Bu disiplinin coğrafya bilimi gibi çok çeşitli tanımları yapılabilir. Bu tanımların bazıları aşağıda verilmeye çalışılmıştır.

Özey (2007:21)'e göre, siyasi coğrafya "dünyanın tamamında veya bir bölgesinde ya da ülkesinde, doğal beşerî ve ekonomik olayların dağılışını, aralarındaki bağlantılarını, sebep ve sonuçlarını inceleyerek, devlet işlerini düzenleme ve yürütme sanatıyla ilgili özel görüş veya anlayış belirleyen bir bilimdir". Akengin (2013:6) siyasi coğrafyayı "insanın eseri olan siyasal organizasyonlar ve siyasal faaliyetlerin, coğrafi faktörlerle ilişkilerini incelemektedir" şeklinde tanımlamıştır. Tüm bu tanımları da dikkate alarak siyasi coğrafyayı "hem dünya siyasetinde hem de tek tek ülkelerin izlediği siyasette coğrafi faktörlerin etkisini araştıran" bir disiplin olarak düşünebiliriz. Yine siyasi coğrafya ile yakından ilişkili jeopolitik kavramı üzerinde de durmak gerekir. İlhan (1993:4) tarafından jeopolitik, "coğrafi niteliklerin yönlendirdiği politika olarak" tanımlanmaktadır. Atalay (2004) ise jeopolitiği "coğrafi konuma göre devlet idare etme sanatı, siyaseti” şeklinde açıklamıştır. Sonuç olarak; 20. yy.'nin 
ikinci yarısından itibaren popülaritesi artan jeopolitik kavramını ve bu kavram altında yer alan konu başlıklarını siyasi coğrafya altında düşünmek gerekir.

Hem dünyayı hem de yaşadıkları ülkeyi çok iyi tanıyan milletlerin ve buna göre planlamalar yapabilen ülkelerin dünya ve bölge siyasetinde etkinlikleri fazla olabilir. Demirci (20005)'nin "günümüz ülkelerinin dünya siyaset arenasında ekonomik ve siyasal yönden güçlü olmalarının matematik ve özel konumlarından en üst düzeyde istifade edebilmeleriyle olduğu gibi başta yakın komşuları olmak üzere dünya ülkelerini fiziki, beşerî ve kültürel yönden iyi tanımalarıyla yakından alakalı olduğu" şeklindeki görüşü bu duruma dikkat çekmektedir. Dünyada meydana gelen siyasal olayların dağılışını ve nedenlerini, çatışma bölgelerini, ülkelerin jeopolitik özelliklerini, devletlerin güç ve etkinliklerini analiz ederek açıklayabilme ve yorumlayabilme gibi yeterlilikleri öğrencilerin kazanmalarında siyasi coğrafya öğretiminin önemi büyüktür. Sonuç olarak; ülkesini ve dünyayı tanıyan gençler yetişmesi noktasında yukarıdaki önemine dikkat çekmeye çalıştığımız coğrafya biliminin ve özelde de siyasi coğrafya disiplinin ilköğretimden başlayarak ülkemizde eğitimin her kademesindeki öğretimi çok önemlidir. Bu çalışmada da yukarıda ortaya koymaya çalıştığımız öneminden dolayı lise coğrafya öğretim programındaki siyasi coğrafya konularına ilişkin öğrenci başarıları üzerinde öğretmen görüşleri doğrultusunda durulmaya çalışılmıştır.

Öğrenci başarısı, “öğrencinin birtakım bilgi ve beceri kazanmayı gerektiren konularda istenilen düzeyde yeterlilik göstermesi ya da kendisine ölçme araçları uygulanan öğrencinin olumlu tepkileriyle ortaya çıkan sonuçtur" (Koçak, 1993:18). Genellikle eğitimde başarı kavramıyla akademik başarı vurgulanmaktadır. Carter'e göre akademik başarı, "herhangi bir okulda okutulan derslerde geliştirilen ve ögretmenlerce takdir edilen notlarla, test puanlarıyla ya da her ikisi ile belirlenen beceriler ya da kazanılan bilgilerdir" (aktaran Sarıer, 2016: 610). Okula giden her öğrenciden beklenen en önemli sonuç akademik başarıdır. Akademik başarı, öğrencilerin toplumsal hayata ve mesleğe donanımlı şekilde hazırlanmalarını sağladığı için aile ve çevre açısından da oldukça önemli görülmektedir. Öğrencilerin aktif olarak derslere katılımının sağlandığı yöntemlerle öğrencilerin derslerdeki akademik başarıları artmaktadır. Eğitim açısından bakıldığında ise başarı, öğrencinin ders müfredatında belirtilen hedef ve kazanımları kavraması ve bu doğrultuda davranış sergilemesidir. Pek çok ders için olduğu gibi lisedeki coğrafya derslerinin öğretim programında yer alan siyasi coğrafya ile ilişkili kazanımların ve konuların öğrenciler tarafından kavranması yukarıda da belirttiğimiz gibi çok önemlidir. Lise Coğrafya Dersi Öğretim Programında farklı sınıflarda küresel ortam öğrenme alanı altında siyasi coğrafya konuları yer almaktadır. Bu konular; 11. sinıfta bölgesel ve küresel örgütler, 12. sınıfta ise tarihsel süreçte Türkiye'nin jeopolitik konumu ve çevresindeki bölgesel sorunlar, dünyadaki sıcak çatışma bölgeleridir (MEB, 2018: 12; 44). Bu konulara bağlı öğrencilerden beklenen hedef, davranış ve kazanımlar ile coğrafi beceriler Tablo 1'de belirtilmiştir.

Tablo 1: Siyasi Coğrafya Konularına Ait Hedef, Davranış ve Kazanımlar-Coğrafi Beceriler

\begin{tabular}{|c|c|c|}
\hline Konular & Hedef, Davranış ve Kazanımlar & Coğrafi Beceriler \\
\hline Küresel ve bölgesel örgütler & $\begin{array}{l}\text { Bölgesel ve küresel ölçekteki } \\
\text { örgütleri, etki alanları açısından } \\
\text { değerlendirir. }\end{array}$ & Coğrafi sorgulama \\
\hline $\begin{array}{l}\text { Tarihsel süreçte Türkiye'nin } \\
\text { jeopolitik konumu }\end{array}$ & $\begin{array}{l}\text { Tarihsel süreçte Türkiye'nin } \\
\text { jeopolitik konumunu değerlendirir. }\end{array}$ & $\begin{array}{l}\text { Değişim ve sürekliliği algılama } \\
\text { Coğrafi sorgulama }\end{array}$ \\
\hline $\begin{array}{l}\text { Türkiye'nin çevresindeki bölgesel } \\
\text { sorunlar }\end{array}$ & $\begin{array}{l}\text { Türkiye'nin içinde yer aldığı } \\
\text { jeopolitik bölgelerle olan iliş̧kisini } \\
\text { açıklar. }\end{array}$ & $\begin{array}{l}\text { Harita becerisi } \\
\text { Coğrafi sorgulama }\end{array}$ \\
\hline Sıcak çatışma bölgeleri & $\begin{array}{l}\text { Ülkeler arasında sorun oluşturan } \\
\text { mekânsal unsurları günümüz } \\
\text { çatışma alanlarıyla ilişkilendirir. }\end{array}$ & $\begin{array}{l}\text { Değişim ve sürekliliği algilama } \\
\text { Harita becerisi } \\
\text { Coğrafi sorgulama }\end{array}$ \\
\hline
\end{tabular}


Türkiye'de son yıllarda siyasi coğrafya ve jeopolitik üzerinde yapılan çalışmalar yaygınlaşmış olsa da siyasi coğrafya öğretimi üzerine yapılmış araştırma son derece azdır. Özellikle de lise coğrafya öğretimindeki siyasi coğrafya konuları ile ilgili çalışmalar çok daha azdır. Bu çalışmalar aşağıda verilmeye çalışılmıştır:

Deniz (2010) araştırmasında; buluş yoluyla öğretim yaklaşımının siyasi coğrafya konularının öğretiminde öğrenci başarısı üzerindeki etkisini belirlemeyi amaçlamıştır. Buluş yoluyla öğretim yaklaşımının, ortaöğretim coğrafya öğretim programında yer alan siyasi coğrafya konularının öğretiminde başarı ile uygulanabileceği ve bu yaklaşım ile konuların daha anlamlı ve uzun süreli öğretilebileceği sonucuna ulaşmıştır.

Tozo (2011) araştırmasında; lisedeki Türkiye'nin jeopolitiği ve çevresindeki bölgesel sorunlar konusunda kavramların öğrenciler tarafından öğrenilmesinde, probleme dayalı öğrenmenin geleneksel yaklaşımdan daha etkili olduğu ortaya çıkmıştır. Yine öğrencilerin coğrafya dersine karşı tutumları ve problem çözme becerileri açısından da probleme dayalı öğrenme lehine gruplar arasında anlamlı bir farklılığın olduğu tespit edilmiştir.

Demirci (2005) çalışmasında; günümüzde Türkiye'nin, içinde bulunduğu coğrafyada iç ve dış siyasette giderek yoğunlaşan problemlerle karşı karşıya geldiğini; ekonomik, sosyal ve kültürel yönden topyekûn kalkınmasını sağlayabilmesi ve dış siyasette problemlerin üstesinden gelebilmesi, geleceğin dünyasında iyi bir mevki edinebilmesi için Türkiye'nin daha önce hiç ihtiyaç duymadığ 1 ölçüde çağdaş coğrafya bilimine ve bu bilimin ileri metot, teknik ve araç gereçlerine ihtiyacı olduğu sonucuna varmıştır.

Türkiye'de liselerdeki siyasi coğrafya konularının öğretimi ile ilgili yayınların azlığı çalışmanın önemini artırmaktadır.

\section{Yöntem}

Araştırmanın bu bölümünde, araştırmanın modeli, çalışma grubu, araştırmada kullanılan veri toplama aracının uygulanması ve verilerin analiziyle ilgili bilgilere yer verilmiştir.

\subsection{Araștırma Deseni}

$\mathrm{Bu}$ araştırmada Giresun ilinde MEB'e bağlı ortaöğretim kurumlarında çalışan yirmi coğrafya öğretmeniyle görüşmeler yapılmıştır. Araştırma, coğrafya dersi siyasi coğrafya konularına yönelik öğrencilerin başarı düzeylerinin öğretmen görüşlerine göre değerlendirilmesini amaçlayan nitel bir çalışmadır.

"Nitel araştırma gözlem, görüşme ve doküman analizi gibi veri toplama yöntemlerinin kullanıldığı, algıların ve olayların doğal ortamda gerçekçi ve bütüncül bir biçimde ortaya konmasını sağlayan bir sürecin izlendiği araştırma olarak tanımlanabilir" (Yıldırım ve Şimşek, 2013:45).

Bu çalışmanın desenini nitel araştırma türlerinden olgu bilim (fenomenoloji) oluşturmaktadır. Creswell'e (2007) göre; olgu bilim çalışmalarında tüm katılımcıların bir olguya ilişkin deneyimleri ortaya koyulmaya çalışılır. Yıldırım ve Şimşek (2013)'in de belirttiği gibi bu çalışmalar farkında olduğumuz ancak derinlemesine ve ayrıntılı bir anlayışa sahip olmadığımız olgulara odaklanmaktadır. Yine olgu bilim çalışmalarında en çok kullanılan veri toplama tekniği görüşmedir.

\section{1 Çalışma Grubu}

"Olgu bilim araştırmalarında veri kaynakları araştırmanın odaklandığı olguyu yaşayan ve bu olguyu dışa vurabilecek veya yansıtabilecek bireyler ya da gruplardır" (Yıldırım ve Şimşek, 2013:74). $\mathrm{Bu}$ araştırmanın çalışma grubunu orta öğretim kurumlarında görevli 20 coğrafya öğretmeni oluşturmaktadır. Görüş̧me yapılacak öğretmenler seçilirken çalıştıkları okul türlerinin farklı olmasına dikkat edilmiştir. Görüşme yapılan altı öğretmen Anadolu Lisesinde, iki öğretmen Fen Lisesinde, iki 
öğretmen Sosyal Bilimler Lisesinde, beş öğretmen Anadolu İmam Hatip Lisesinde, üç öğretmen Mesleki ve Teknik Anadolu Lisesinde iki öğretmen ise Çok Programlı Anadolu Lisesinde görev yapmaktadır (Tablo 2).

Tablo 2: Araştırmaya Katılan Öğretmenler Hakkında Bilgiler

\begin{tabular}{llll}
\hline Kod & Cinsiyet & Kıdem (Yı) & Çalıştı̆̆ı Okul Türü \\
\hline Ö1 & Erkek & $11-15$ & Anadolu Lisesi \\
Ö2 & Erkek & $1-5$ & Çok Programlı Anadolu Lisesi \\
Ö3 & Erkek & 21 yıl üzeri & Anadolu Lisesi \\
Ö4 & Erkek & $16-20$ & Sosyal Bilimler Lisesi \\
Ö5 & Kadın & $6-10$ & Anadolu İmam Hatip Lisesi \\
Ö6 & Erkek & $16-20$ & Anadolu Lisesi \\
Ö7 & Erkek & 21 yıl üzeri & Sosyal Bilimler Lisesi \\
Ö8 & Erkek & 21 yıl üzeri & Anadolu Lisesi \\
Ö9 & Kadın & $11-15$ & Mesleki ve Teknik Anadolu Lisesi \\
Ö10 & Erkek & $1-5$ & Mesleki ve Teknik Anadolu Lisesi \\
Ö11 & Kadın & $11-15$ & Anadolu Lisesi \\
Ö12 & Kadın & $11-15$ & Fen Lisesi \\
Ö13 & Kadın & $6-10$ & Anadolu İmam Hatip Lisesi \\
Ö14 & Erkek & $11-15$ & Fen Lisesi \\
Ö15 & Kadın & $1-5$ & Anadolu İmam Hatip Lisesi \\
Ö16 & Erkek & 21 yıl üzeri & Mesleki ve Teknik Anadolu Lisesi \\
Ö17 & Erkek & $11-15$ & Anadolu İmam Hatip Lisesi \\
Ö18 & Kadın & $11-15$ & Anadolu İmam Hatip Lisesi \\
Ö19 & Erkek & $1-5$ & Çok Programlı Anadolu Lisesi \\
Ö20 & Kadın & $6-10$ & Anadolu Lisesi \\
\hline
\end{tabular}

Çalışma grubundaki öğretmenlerin \%60'1 erkek öğretmenlerden, \%40’1 kadın öğretmenlerden oluşmaktadır. Yine görüşme yapılan 20 öğretmenden; 4'ü 1-5 yıl arası, 3’ü 6-10 yıl arası, 7'si 11-15 yıl arası, 2'si 16-20 yıl arası, 4'ü ise 21 yıl ve üzeri kıdeme sahiptir (Tablo 2). Yukarıdaki açıklamalardan da anlaşıldığı gibi çalışma grubunu farklı özellikteki öğretmenlerin oluşturmasına dikkat edilmiştir. Çalışma grubunun oluşturulmasında "maksimum çeşitlilik" örneklem oluşturma yöntemi kullanılmıştır. Neuman (2014)'ın belirttiği gibi maksimum çeşitlilik yöntemi ile incelenen olay veya olguyla ilişkili çok sayıda farklılığı kapsayan ana temaları keşfetmek ve tanımlamak amaçlanmaktadır (aktaran Baltacı, 2018:249). Bu örneklem oluşturma yöntemi ile oluşturulan çalışma grubunun farklı özellikleri gösteren bireylerden oluşmasının gayesi genelleme yapmak değil olay ve olguya farklı açılardan bakabilmektir.

\subsection{Veri Toplama Aracı}

$\mathrm{Bu}$ araştırmada konunun amacına ve içeriğine en uygun olduğu düşünülen, aynı zamanda nitel araştırma yöntemlerinden en sık kullanılanı olan görüşme tekniği kullanılmıştır. "Görüşme en az iki kişi arasında sözlü olarak gerçekleştirilen bir iletişim sürecidir. Görüşme, araştırmada cevabı aranılan sorular çerçevesinde ilgili kişilerden veri toplama şeklinde ifade edilebilir" (Büyüköztürk ve diğerleri, 2013:150). Görüşme tekniği ile bir araştırma konusu veya bir soru hakkında derinlemesine bilgi sağlanabilmektedir. Çalışmada yarı yapılandırılmış görüşme yapılmıştır. "Yarı yapılandırılmış görüşme tekniği, araştırılan temaya yönelik kapsamlı veriyi temin etmek için, katılımcıların iç dünyalarını anlamaya, sahip oldukları bilgi, deneyim ve davranışlarını betimlemeye yönelik bir tekniktir" (Özgen, 2016:161).

Bu çalışmada görüşme soruları hazırlanmadan önce Coğrafya Dersi Öğretim Programı (CDÖP) ve coğrafya dersi yıllık planları incelenmiş yani doküman analizi yapılarak siyasi coğrafya konuları belirlenmiştir. Öğretim programının kazanım, beceri, değer, etkinlikler, ölçme ve değerlendirme boyutları da incelendikten sonra siyasi coğrafya konu ve kazanımlarına yönelik olarak araştırma soruları 
hazırlanmıştır. Görüşme formundaki sorular ile coğrafya dersine giren iki öğretmenle ön görüşme gerçekleştirilmiş ve bu görüşme sırasında soruların anlaşılmayan yerleri varsa öğretmenlerin ifade etmeleri istenmiştir. Son olarak hazırlanan görüşme formu, biri doçent, biri doktor öğretim üyesi olmak üzere iki alan uzmanına gösterilmiş ve onayları alınmıştır. Yapılan tüm bu çalışmaların ölçme aracının güvenirliğini artığı söylenebilir. Görüşme formunda CDÖP' de yer alan her bir siyasi coğrafya konusu ile ilgili bu konu bağlamında öğrencilerin başarı düzeylerini ölçmeye yönelik "başarılı", "büyük ölçüde başarıllı", "kısmen başarıl1", "az başarıllı" ve "başarısız" likertlerinin olduğu çoktan seçmeli soru bulunmaktadır. $\mathrm{Bu}$ soruya verilen cevaba göre öğretmenlere yöneltilecek olan; "öğrencilerin başarısızlıklarının nedenleri neler olabilir?" veya "öğrencilerin başarılarının nedenleri neler olabilir? soruları ölçme aracında yer almaktadır.

\subsection{Verilerin Toplanması ve Analizi}

Verilerin toplanması için, gerekli kurumlardan izin alınmış, 2018 - 2019 eğitim-öğretim yılında 18 farklı okulda görev yapmakta olan 20 coğrafya öğretmeniyle görüşme yapılmıştır. Görüşmeler yapılmadan önce katılımcılardan randevu alınmış ve randevuların özellikle ders çıkış saatlerinden sonra olmasına dikkat edilmiştir. Öğretmenlerle yapılan görüşmelerin tamamı uygulama yapılan öğretmenlerin çalıştıkları kurumlarda öğretmenler odası ve uygun sınıf ortamlarında gerçekleştirilmiştir. Araştırmanın güvenilirliği ve geçerliliğini arttırmak için doğrudan görüşmeye geçilmemiş ve görüşmeye başlamadan önce katılımcıların kendilerini rahat hissetmeleri için siyasi coğrafya üzerine kısa sohbetler yapılmıştır. Daha sonra görüşme kılavuzu doğrultusunda araştırmanın amacı ve görüşme ile neyin hedeflendiği katılımcıya ifade edilmiştir. Görüşme sırasında katılımcılara, soruları rahatlıkla yanıtlamaları için yeterli süre tanınmıştır. Görüşmelerde katılımcılar herhangi bir şekilde yönlendirilmemiş, bireysel yorumlardan uzak durulmuştur. Sonuç olarak araştırmanın güvenirliğini artırmak için görüşmenin uygun ortamlarda gerçekleştirilmesine dikkat edilmiştir.

Araştırmanın verilerinin analizi kısmında; görüşme yapılan öğretmenlerin gerçek isimleri etik kurallar gereği gizli tutulmuştur. Elde edilen görüşme verilerinin analizi için her öğretmene bir kod ad verilmiştir. Öğretmenler birinci öğretmenden yirminci öğretmene kadar Ö1, Ö2, Ö3, Ö4.......̈20 şeklinde kodlanmışlardır. Yapılan görüşmeler sonucu kayıt altına alınan veriler Microsoft Word programında yazılarak bilgisayar ortamına aktarılmıştır. Bilgisayar ortamına atılan verilerin yazılı bir rapor haline getirilmesinden sonra verilerin analizine geçilmiştir. Araştırmada içerik analiz yöntemi kullanılmıştır. "İçerik analizinde temel amaç, toplanan verileri açıklayabilecek kavramlara ve ilişkilere ulaşmaktır. İçerik analizinde temelde yapılan işlem, birbirine benzeyen verileri belirli kavramlar ve temalar çerçevesinde bir araya getirmek ve bunları okuyucunun anlayabileceği bir biçimde düzenleyerek yorumlamaktır" (Yıldırım ve Şimşek, 2013:259). İçerik analizi, toplanan verilerin ayrıntılı bir şekilde analiz edilmesini gerektirir ve önceden belirli olmayan boyutların ortaya çıkarılmasına olanak sağlar. Araştırmada öğretmenlerin vermiş oldukları cevaplar incelenerek öğrencilerin konu bağlamında başarıları üzerinde etkili olan faktörler belirlenmiş ve bunlara frekanslar verilmeye çalışılmıştır.

\section{Bulgular}

Araştırmanın bu bölümünde ortaöğretim CDÖP' de bulunan; tarihsel süreçte Türkiye'nin jeopolitik konumu, Türkiye'nin çevresindeki bölgesel sorunlar, küresel ve bölgesel örgütler ve sicak çatışma bölgeleri siyasi coğrafya konularının her biri için öğrencilerin başarı düzeyleri ve başarı üzerinde etkili olan faktörler öğretmen görüşleri doğrultusunda ortaya koyulmaya çalışılmıştır.

\subsection{Tarihsel Süreçte Türkiye'nin Jeopolitik Konumu Konusunda Öğrenci Başarılarına Yönelik Öğretmen Görüşleri}

Araştırmaya katılan öğretmenlerin "tarihsel süreçte Türkiye'nin jeopolitik konumu” konusu ile ilgili öğrencilerin başarı düzeylerine yönelik görüşleri Tablo 3'de verilmiştir. Bu tablo incelendiğinde; öğretmenlerin \%60’’ bu konuda öğrencileri başarılı ve büyük ölçüde başarılı bulmaktadır. 
Tablo 3: Tarihsel Süreçte Türkiye'nin Jeopolitik Konumu Konusunda Öğrencilerin Başarı Düzeylerine Yönelik Öğretmen Görüşlerinin Dağılımı

\begin{tabular}{lcc}
\hline Başarı Düzeyleri & f & \% \\
\hline Başarılı & 4 & 20 \\
Büyük Ölçüde Başarılı & 8 & 40 \\
Kısmen & 4 & 20 \\
Az Başarılı & 3 & 15 \\
Başarısız & 1 & 5 \\
\hline Toplam & 20 & 100 \\
\hline
\end{tabular}

Araştırmaya katılan öğretmenlerin "tarihsel süreçte Türkiye'nin jeopolitik konumu” konusunda öğrenci başarılarını etkileyen faktörler hakkındaki görüşleri ise Tablo 4'de ortaya koyulmuştur. $\mathrm{Bu}$ tabloda; öğrencileri ilgili konu bağlamında başarılı ve büyük ölçüde başarılı bulan öğretmenlerin cevapları başarıyı artıran; öğrencileri kısmen başarılı, az başarılı ve başarısız bulan öğretmenlerin cevapları ise başarıyı azaltan faktörler altında verilmeye çalışılmıştır. Tablo incelendiğinde; öğrencileri ilgili konu bağlamında kısmen başarılı, az başarılı ve başarısız bulan öğretmenlere göre başarısızlık üzerinde "öğrencileri siyasete karşı ilgisiz olmaları" ve "harita bilgilerinin yetersiz olması" en etkili olan faktörlerdir. Konu bağlamında öğrencileri başarılı bulan öğretmenlere göre ise; başarı üzerinde "öğrencilerin konu hakkında ön bilgilerinin olması", "tarih dersiyle konunun bağlantısının olması" ve "öğrencilerin siyasi coğrafyaya karşı ilgili olmaları" faktörleri öne çıkmaktadır. Bu konu ile ilgili başarıyı etkileyen faktörlere genel olarak bakıldığında ise; başarıyı artıran faktörlerin başarıyı azaltan faktörlere göre baskın olduğu söylenebilir (Tablo 4). Tabi burada başarıyı artıran faktörlerin toplam frekansının öğretmen sayısından fazla olması; bir öğretmenin birden fazla faktörle ilgili cevap vermesi ile ilişkilidir.

Tablo 4: Tarihsel Süreçte Türkiye'nin Jeopolitik Konumu Konusunda Başarıyı Etkileyen Faktörler

\begin{tabular}{|c|c|c|c|}
\hline Başarıyı Artıran Faktörler & $\mathbf{f}$ & Başarıyı Azaltan Faktörler & $\mathbf{f}$ \\
\hline $\begin{array}{l}\text { Öğrencilerin konu hakkında ön } \\
\text { bilgilerinin olması }\end{array}$ & 7 & $\begin{array}{l}\text { Öğrencilerin siyasete karşı ilgisiz } \\
\text { olmaları }\end{array}$ & 6 \\
\hline $\begin{array}{l}\text { Tarih dersiyle konunun bağlantısının } \\
\text { olması }\end{array}$ & 6 & Harita bilgilerinin yetersiz olması & 3 \\
\hline $\begin{array}{l}\text { Öğrencilerin siyasi coğrafyaya karşı ilgili } \\
\text { olmaları }\end{array}$ & 5 & Öğrencilerin konuyu sıkıcı bulmaları & 2 \\
\hline $\begin{array}{l}\text { Siyasi coğrafya konularının günlük } \\
\text { yaşamla ilgili olması }\end{array}$ & 3 & $\begin{array}{l}\text { Öğrencilerin üniversite sınavına } \\
\text { yoğunlaşması }\end{array}$ & 2 \\
\hline $\begin{array}{l}\text { Üniversite sinavlarında konudan soru } \\
\text { gelmesi }\end{array}$ & 3 & $\begin{array}{l}\text { 12. sınıfta devamsızlıkların artması } \\
\text { Öğrencilerin önbilgi eksikliğı }\end{array}$ & 2 \\
\hline Öğrencilerin bu konuları merak etmeleri & 2 & $\begin{array}{l}\text { Eleştirisel ve yaratıcı düşünme becerilerin } \\
\text { az olması }\end{array}$ & 1 \\
\hline Konunun güncel olması & 2 & & \\
\hline
\end{tabular}

Görüşme yaptığımız öğretmenlerden öğrencilerin başarı düzeyleri hakkında olumlu görüş bildirenlerden bazılarının cevapları aşağıda verilmiştir:

Ö3: Öğrencilerin jeopolitik kavramına karşı ilgi düzeyleri yüksek. Siyasi coğrafyaya ilginin yüksek olması, başarı düzeyini de artırmaktadır. Ayrıca ögrencilerin bu konularda ortaokulda 
ve 9. ve 10. sinıflardan ön bilgileri bulunmaktadır. Yine disiplinler arası yaklaşıma bağlı olarak tarih dersinden de bilgilerinin olması başartyı artırtyor.

Ö6: Konulardan üniversite sinavinda ögrencilere soru sorulması. Aynı zamanda kavramların tarih dersinde de ögrencilere ögretilmesi. Ögrencilerin politikaya ilgili ve duyarlı olması, siyasi coğrafya konularının günlük yaşamla ilgili olması ve güncel olması başarının yüksek olmasında etkili olmaktadır.

Ö11: Çocukların ilgisini çeken bir konu, aynı zamanda üniversite sınavı konusu olması, tarih bilgisini de kullanıyor olmaları hoşlarına gidiyor. Jeopolitik, jeostrateji, küreselleşme gibi kavramları ögrenmek ögrencilerde özgüven yaratıyor.

Ö12: Tarih dersinin burada etkisi büyük. Ayrıca 10. sınıfta bu konunun işlenmiş olması ögrencilerde belirli bir temel oluşturmuş durumda. Türkiye'nin mutlak ve göreceli konumunu daha önceki yıllarda görmüş olmaları başarının artmasında önemli bir faktör.

Ö16: Geçmişini bilmeyen geleceğine yön veremez diyerek motivasyonlarını sağlamaktayım. Bu motivasyon ögrencilerin bu konuya ilgi duymalarını, merak etmelerini să̆llyor. Öğrencilerde ilgi ve merak oluşturmak başartyı artırlyor.

Ö18: Öğrenciler tarih dersinde de bu konuları görmüş olduğu için konuya hâkim durumdalar. Ayrıca ülkemizin siyasi durumu ve şu an da dünya gündeminin de hareketli oluşu konuyu çekici hale getiriyor. Kısacası güncellik ve önbilgilerinin varlı̆̆ diyebilirim.

$\mathrm{Bu}$ konuda öğrencilerin başarı durumu hakkında olumsuz görüş bildiren öğretmenlerden bazılarının cevapları aşağıda verilmiştir:

Ö5: Öğrencilerin başarısızlı̆gıdaki en büyük faktör konuya karşı ilgi duymamalarıdır. Ayrıca konu 12.sınıf konusu olduğu için ögrencilerin bu dönemde devamsızlığı artmakta, ögrrencilerin üniversite sinavina yönelmeleridir.

Ö9: Öğrencilerin genel olarak dünya ve Türkiye siyasetinden uzak kalmalart en önemli problem. Harita becerilerinin çok yetersiz olması ve konuyu sıkıcı bulmaları diğer faktörler.

Ö14: Öğrencilerimizin bu konuda hatta coğrafya konularına karşı ilgi düzeyi düşük. Özellikle fen liselerinde bu derse karşı olumsuz bir bakış açısı mevcut. Öğrenciler sadece üniversite sınavına odaklı ders çalışıyor. Zaten eşit ağırlık alanından sınava girecek olan öğrenciler dersi seçmekte. Onlar da tamamen sınav odaklı düşünmekte. Sayısal bölümlerde 12. sinıf coğrafya dersi zaten seçilmemekte.

Ö17: Öğrenciler Türkiye'nin jeopolitik konumu ile ilgili güncel olayları ve konulart takip etmediklerinden dolayı süreci anlamlandıramıyorlar. Bundan dolayl; Türkiye'nin jeopolitik konuтипи günümüzden geriye doğru irdeleme yetisine sahip değiller. Bu tarz konularda süreci bir bütün olarak anlamlı bir şekilde öğrenme gerekliliği en önemli husustur.

\subsection{Türkiye'nin Çevresindeki Bölgesel Sorunlar Konusunda Öğrenci Başarılarına Yönelik Öğretmen Görüşleri}

Araştırmaya katılan öğretmenlerin "Türkiye'nin çevresindeki bölgesel sorunlar" konusunda öğrencilerin başarı durumuna yönelik görüşleri Tablo 5'de verilmiştir. Bu tablo incelendiğinde; öğretmenlerin \%40'1 bu konuda öğrencileri kısmen başarılı bulmaktadır. İlgili konu bağlamında; öğrencileri kısmen başarılı bulanları, başarısız ve az başarılı bulanlarla birlikte düşündügüüüzde ise ögretmenlerin \%60'1 öğrencileri yeterince başarılı bulmamaktadır ve bu durumda bir sorundur. 
Tablo 5: Türkiye'nin Çevresindeki Bölgesel Sorunlar Konusunda Öğrencilerin Başarı Düzeylerine Yönelik Öğretmen Görüşlerinin Dağılımı

\begin{tabular}{lcc}
\hline Başarı Düzeyleri & f & \% \\
\hline Başarılı & 4 & 20 \\
Büyük Ölçüde Başarılı & 4 & 20 \\
Kısmen & 8 & 40 \\
Az Başarılı & 3 & 15 \\
Başarısız & 1 & 5 \\
\hline Toplam & 20 & 100 \\
\hline
\end{tabular}

Araştırmaya katılan öğretmenlerin “Türkiye'nin çevresindeki bölgesel sorunlar” konusunda öğrenci başarılarını etkileyen faktörler ile ilgili görüşleri Tablo 6'da ortaya koyulmuştur. Bu tablo incelendiğinde; öğrencileri ilgili konu bağlamında başarılı bulmayan öğretmenlere göre başarısızlık üzerinde "öğrencilerin konuya ve güncel olaylara karşı ilgisizlikleri, eleştirel düşünme ve problem çözme becerilerindeki eksiklikler" en fazla etkili olan faktörlerdir. Konu bağlamında öğrencileri başarılı bulan öğretmenlere göre ise; başarı üzerinde "konunun öğrencilerin yakın çevrelerini ilgilendirmesi ve tarih bilgilerini konu işlenirken kullanmaları ve ön öğrenmeleri ile bölgesel sorunlara medyada sık sık yer verilmesi” öne çıkan etkenlerdir. Genel olarak düşündüğümüzde; ilgili konu bağlamında başarıyı etkileyen faktörler içinde başarıyı azaltan faktörler de önemlidir.

Tablo 6: Türkiye'nin Çevresindeki Bölgesel Sorunlar Konusunda Başarıyı Etkileyen Faktörler

\begin{tabular}{|c|c|c|c|}
\hline Başarıyı Artıran Faktörler & $\mathbf{f}$ & Başarıyı Azaltan Faktörler & $\mathbf{f}$ \\
\hline $\begin{array}{l}\text { Konunun öğrencilerin yakın çevrelerini } \\
\text { ilgilendirmesi }\end{array}$ & 5 & Konuya ve güncel olaylara karşı ilgisizlik & 5 \\
\hline $\begin{array}{l}\text { Tarih bilgilerini konu işlenirken } \\
\text { kullanmaları ve ön öğrenmeler }\end{array}$ & 5 & $\begin{array}{l}\text { Eleştirel düşünme ve problem çözme } \\
\text { becerilerinin eksikliği }\end{array}$ & 5 \\
\hline $\begin{array}{l}\text { Bölgesel sorunlara medyada s1k s1k yer } \\
\text { verilmesi }\end{array}$ & 5 & $\begin{array}{l}\text { Öğrencilerin ilgi alanlarının magazin, } \\
\text { futbol, oyun vb. etkinlikler olması }\end{array}$ & 3 \\
\hline Konunun güncel olmas1 & 3 & $\begin{array}{l}\text { Araştırma yapma alışkınlıklarının } \\
\text { olmaması }\end{array}$ & 3 \\
\hline $\begin{array}{l}\text { Öğrencilerin siyaset ve politikaya karş1 } \\
\text { ilgili olmaları }\end{array}$ & 3 & $\begin{array}{l}\text { Öğrencilerin aktif öğrenme yöntemleriyle } \\
\text { ders işlenmesinden çok hoşnut } \\
\text { olmamaları }\end{array}$ & 2 \\
\hline $\begin{array}{l}\text { Aktif öğrenme yöntemlerinin konunun } \\
\text { öğretimde kullanılması }\end{array}$ & 2 & & \\
\hline
\end{tabular}

Görüşme yaptığımız öğretmenlerden bu konuda öğrencilerin başarı durumu hakkında olumlu görüş bildiren katılımcılardan bir kısmının cevapları aşağıda verilmiş̧tir:

Ö4: Konuların güncel olması bence en önemli faktördür. Özellikle sinır bölgelerimizdeki olaylar öğrencinin ilgisini çekmekte bu durum ögrrenciyi ayrıca araştırma yapmaya itmekte, farkl yerlerden konuyla ilgili öğrenme gerçekleştirmesine neden olmakta.

Ö6: Öğretim ilkeleri gereği; yakın çevreden uzağa ilkesi gereğince yerel, bölgesel ve küresel ölçekteki güncel konulara ă̆ırlık verilmesi, konudaki başarı düzeyini artırmaktadır. Öğrenciler genellikle hemen çevremizde yaşanan Suriye, Irak ve terör gibi sorunlarda kendi yaşamların da ilgilendirdiğinden başarı düzeyi artmaktadır. Sik sik gazete ve televizyonlarda bu konulara değinilmesi, ögrencilerin bu yayınları takip etmesi diğer bir etkendir. 
Ö11: Devaml medyadan ve sosyal ortamlarından duydukları konular olması algılarını tamamen konuya yönlendirmelerini săgllyor bu da başartyı artırtyor. Bu durum derse katılımlarını da artırmakta, derste sık sı sormaktadırlar. Aynı zamanda beyin firtınası, tartışma gibi aktif öğrenme yöntemlerinin konuyu işlemeye uygun olmast.

Ö13: Ö̈rrenciler bu konu ile ilgili sorulan sorulara büyük ölçüde cevap verebiliyor. Bunda genel gündemi takip etmeleri geliyor. Özellikle sinır bölgelerimizdeki olaylarla ilgili dersten ziyade televizyon, gazete ve internet gibi kaynaklardan da bilgi sahibi oluyorlar. Yaş itibariyle de genel olarak politikaya karşı belli bir ilgileri var.

Ö15: Öğrencilerin ülke siyasetini takip etmesi, yaş itibariyle politikaya ilgi duymasl, bu konuların genel kültür açısından önemli olduğunun farkında olmaları derse karşı ilgiyi artırıyor. Ayrıca geçmiş coğrafya ve tarih bilgileri de başarının artmasında diğer bir neden.

$\mathrm{Bu}$ konuda öğrencilerin başarı durumu için olumsuz görüş bildiren bazı öğretmenlerin verdiği cevaplar aşağıda verilmiştir:

Ö5: Öğrenciler konuya ilgili olsa bile araştırma yapma alışkanlıklarının zayıf olması, ögrencilerin konu tekrarı yapmaması ve ezbere yönelik ders çalışması, aktif öğrenme yöntemlerini ders işlenişinde kullanmamaları diyebiliriz.

Ö10: Siyaset ve politikadan ziyade ögrencilerin ilgi alanının magazin ve spor olması başarısızlı̆̆ın en önemli nedenleridir. Ayrıca ögrencilerin eleştirisel dü̧̈ünme, problem çözme ve yorum yapma gibi becerileri maalesef çok kisitll.

Ö12: Aslında ülkenin jeopolitik konumu ile çevresinde yaşanan sorunlar bağlantılı olduğu için ögrenciler konuya yabancı değil. Ön ögrenmelerin varlı̆̆ başarıyı artırsa da ögrencilerin ders sırasında kendini ifade etmemesi, yorum yapmamasl, tartışmaya girmemesi başarıyı düşürüyor. Ö17: Türkiye'nin çevresindeki güncel olaylarla ilgili pek fazla malumata sahip değiller. Bu durumdan dolayı etrafimızdaki bölgesel sorunlar ilgi alanlarına girmiyor. Illgi duymadıkları bir konuda kalıcı bilgiler yapılandıramıyorlar. Bilgilerin kalıcı olamaması başarılarını olumsuz etkiliyor.

Ö20: Öğrencilerin araştırma yapma, sorgulama, problem çözme, tartışma gibi becerilerden yoksun olması başarı düzeyini düsürmekte. Genellikle hazır bilginin ögretmenler tarafindan verilmesini bekliyorlar. Halen öğretim ortamında öğretmen merkezli, anlatım yönteminin uygulanması bekliyorlar.

\section{Görüşleri}

\subsection{Küresel ve Bölgesel Örgütler Konusunda Öğrenci Başarılarına Yönelik Öğretmen}

Araştırmaya katılan öğretmenlerin "küresel ve bölgesel örgütler" konusunda öğrencilerin başarı durumuna yönelik görüşleri Tablo 7'de gösterilmiştir. Bu tablo incelendiğinde; öğretmenlerin \% $\% 60$ '1 bu konuda öğrencileri kısmen başarılı, az başarılı ve başarısız bulmaktadır. Bu sonuç öğrencilerin büyük bir kısmının bu konu bağlamında çok da yeterli olmadıklarını göstermektedir.

Tablo 7: Küresel ve Bölgesel Örgütler Konusunda Öğrencilerin Başarı Durumuna Yönelik Öğretmen Görüşlerinin Dağılımı

\begin{tabular}{lcc}
\hline Başarı Düzeyleri & f & \% \\
\hline Başarııı & 3 & 15 \\
Büyük Ölçüde Başarılı & 5 & 25 \\
Kısmen & 6 & 30 \\
Az Başarılı & 4 & 20 \\
Başarısız & 2 & 10 \\
\hline Toplam & 20 & 100 \\
\hline
\end{tabular}


Araştırmaya katılan öğretmenlerin "küresel ve bölgesel örgütler" konusunda öğrenci başarılarını etkileyen faktörler ile ilgili görüşleri Tablo 8'de gösterilmiştir. Bu tablo incelendiğinde; öğrencileri ilgili konu bağlamında başarılı bulmayan öğretmenlere göre başarısızlık üzerinde "müfredatta örgüt ve örgütlere üye ülke sayısının fazla olması ve üniversite sınavinda konudan soru çıkmaması" en fazla etkili olan faktörlerdir. Konu bağlamında öğrencileri başarılı bulan öğretmenlere göre ise; başarı üzerinde "konunun tarih dersinde de görülüyor olması" öne çıkan etkendir. Yine Tablo 8'e bakıldığında; konu ile ilgili öğrenci başarısını etkileyen faktörlerden başarıyı azaltan faktörlerin daha ağırlıklı olduğu görülür.

Tablo 8: Küresel ve Bölgesel Örgütler Konusunda Başarıyı Etkileyen Faktörler

\begin{tabular}{llll}
\hline Başarıyı Artıran Faktörler & f & Başarıyı Azaltan Faktörler & f \\
\hline $\begin{array}{l}\text { Konunun tarih dersinde de görülüyor } \\
\text { olması }\end{array}$ & 4 & $\begin{array}{l}\text { Müfredatta örgüt ve örgütlere üye ülke } \\
\text { sayısının fazla olması }\end{array}$ & 3 \\
$\begin{array}{l}\text { Konuyu karşı ilgi ve merak } \\
\text { Öğrencilerin konuyla ilgili ön bilgilerinin } \\
\text { olması }\end{array}$ & 3 & $\begin{array}{l}\text { Üniversite sınavında konudan soru } \\
\text { çımaması }\end{array}$ & 3 \\
$\begin{array}{l}\text { Güncel bir konu olması } \\
\text { Konunun öğretiminde görsellerden çok } \\
\text { fazla yaralanma olanağının bulunması }\end{array}$ & 3 & $\begin{array}{l}\text { Soyut bir konu olması ve öğrencilerin } \\
\text { ilgisini çekmemesi }\end{array}$ & 2 \\
$\begin{array}{l}\text { Öğğrencilerin uluslararası örgütleri } \\
\text { toplumsal hayatta çok fazla duymaları }\end{array}$ & 2 & $\begin{array}{l}\text { bilgisinin eksik olması } \\
\text { Konuya karşı motivasyonun kolay } \\
\text { sağlanamaması }\end{array}$ & 2 \\
$\begin{array}{l}\text { Öğrencilerin konuyla ilgili örgütlere yazılı } \\
\text { ve görsel medyada sıklıkla rastlamaları }\end{array}$ & 2 & $\begin{array}{l}\text { Öğrencilerin aktif öğrenme yöntemleriyle } \\
\text { ders işlenmesine alışı olmaması }\end{array}$ & 2 \\
\hline
\end{tabular}

Görüşme yaptığımız öğretmenlerden öğrencilerin başarılı durumu hakkında olumlu görüş bildiren bazı ögretmenlerin cevapları aşağıda verilmiştir:

Ö3: Konuda geçen örgütlere ögrencilerin medyada ve diğer iletişim araçlarında sıklıkla rastlaması. Konunun güncel bir konu olması ve Türkiye'yi de yakından ilgilendiriyor olması.

Ö6: Üniversite sinavinda konudan soru gelmesi, konunun disiplinler arası olarak tarih dersiyle de ilgili olması başarıyı artıran faktörlerdir. Ayrıca birçok örgüte Türkiye'nin de üye olması, güncel bir konu olması ve konu hakkında öğrencileri ön bilgi sahibi olmalarını söyleyebilirim. Ö11: Güncel olması nedeniyle ögrencilerin konuya karşı ilgi düzeyi yüksek. Öğrenciler konu işlenirken aktif olarak derse katıllyorlar. Sorulan sorulara cevap vermeye çalışmaktalar, konuyla ilgili siklıkla görüş bildiriyorlar ve yorum yaplyorlar. Bu ilgi ve merak başarının artmasinda etkili oluyor.

Ö13: Diğer siyasi coğrafya konularındaki başarı oranı kadar yüksek olmasa da bu konuda da genel olarak ögrrenciler başarılı diyebilirim. Özellikle konu içinde birçok örgütün bulunması bu örgütlerin alt dallarının bulunması ve örgütlere birçok ülkenin üye olması ögrencilerde karlşıkliğa neden oluyor. Ancak son dönemde örgüt isimlerini yaşamın içinde çok fazla duymaları da başarıyı olumlu etkiliyor.

Ö15: Konunun özellikle Çağdaş Türk ve Dünya Tarihi dersinde de işlenmesi disiplinler arası bir yaklaşıma neden oluyor. Öğrenciler örgütlere yabancı değiller ve birçoğunu zaten biliyorlar. Kısacası ön bilgilerinin olması başarı oranını artırmakta. 
$\mathrm{Bu}$ konuda öğrencilerin başarı durumları için olumsuz görüş bildiren katılımcıların bir bölümünün cevapları aşağıda verilmiştir:

Ö2: Çocukların ilgisini çekmemesi ve konuların soyut olması. Öğrenciler konuyu sıkıcı ve ezber olarak görüyor. Konuda çok fazla örgüt var ve bu örgütlerle ilgili ders kitabında çok ayrıntıya girilmiş. Bu faktörler birleşince ders işlenirken aktif ögrenme yöntemlerini kullanmak zorlaşlyor.

Ö9: Müfredatta çok fazla örgüt ismi var. Öğrenciler bu örgütleri ve üye ülkeleri hafizalarında tutmakta zorlaniyorlar. Bu durum konunun öğrenciler tarafindan ezber olarak algılanmasina neden oluyor.

Ö14: Okulumuzda sadece eşit ă̆ırlık ögrencilerine yönelik 2 saat seçmeli coğrafya dersi verildiğinden bu kadar kisa sürede bu konuların ögretimi uygun olmamakta. Öğrenciler zaten Temel Yeterlilik Testi konularına yoğunlaşıyor. Bu nedenle bu konuda motivasyon sağlamak zor oluyor. Geçmiş yıllarda üniversite sınavlarında soru gelmemesi zaten ne işime yarayacak ki mantığl oluşturuyor.

Ö17: Bu örgütlerin hangi amaçlar için kurulduğunu yeteri kadar bilmiyorlar. Bu konuları ögrenirken amaçları; Temel Yeterlilik Testi-Alan Yeterlilik Testi (TYT-AYT) sinavlarındaki başarıları olduğu için anlamlı ögrenme gerçekleştiremiyorlar. Sonuçta içselleşemeyen bilgiler kalıcı da olmuyor.

Ö20: Öğrencilerin ülkeleri tanımamaları bilseler dahi dünya üzerindeki yerlerini bilmemeleri, harita bilgilerinin zayıf olması başarısızlıktaki en büyük nedenler olarak görüyorum. Beyin firtınası, tartışma, soru-cevap gibi yöntemleri uygulamaya çalıştı̆̆ımda ya bilgi eksikliğinden ya da yorum becerileri olamadı̆̆ından ögrenciyi aktif olarak sürece dahi edemiyorum. Bu faktörler bir araya gelince başarı da düşük çıkıyor.

\section{Görüşleri}

3.4 Sıcak Çatışma Bölgeleri Konusunda Öğrenci Başarılarına Yönelik Öğretmen

Araştırmaya katılan öğretmenlerin "sıcak çatışma bölgeleri" konusunda öğrencilerin başarı durumuna yönelik görüşleri Tablo 9'da gösterilmiştir. Bu tablo incelendiğinde; öğretmenlerin \%60'ı bu konuda öğrencileri başarılı ve büyük ölçüde başarılı bulmaktadır. Kısmen başarılı bulanların oranı ise $\% 25$ 'dir.

Tablo 9: Sıcak Çatışma Bölgeleri Konusunda Öğrencilerin Başarı Durumuna Yönelik Öğretmen Görüșlerinin Dağılımı

\begin{tabular}{lcc}
\hline Başarı Düzeyleri & f & \% \\
\hline Başarılı & 6 & 30 \\
Büyük Ölçüde Başarılı & 6 & 30 \\
Kısmen & 5 & 25 \\
Az Başarılı & 3 & 15 \\
Başarısız & 0 & 0 \\
\hline Toplam & 20 & 100 \\
\hline
\end{tabular}

Araştırmaya katılan öğretmenlerin "sıcak çatışma bölgeleri” konusunda öğrenci başarılarını etkileyen faktörler ile ilgili görüşleri Tablo 10 'da gösterilmiştir. Bu tablo incelendiğinde; öğrencileri ilgili konu bağlamında başarılı bulmayan öğretmenlere göre başarısızlık üzerinde "öğrencilerin kavram bilgisinin yetersiz olması" en fazla etkili olan faktördür. Konu bağlamında öğrencileri başarılı bulan öğretmenlere göre ise; başarı üzerinde "öğrencilerin "konuyu merak etmeleri” ve "konuya karşı ilgili olmaları" ve "Türkiye'nin jeopolitik konumu gereği sıcak çatışma bölgelerine yakın olması ve bu bölgelerin Türkiye'yi ilgilendirmesi” en etkili etkenlerdir. 
Tablo 10: Sıcak Çatışma Bölgeleri Konusunda Başarıyı Etkileyen Faktörler

\begin{tabular}{|c|c|c|c|}
\hline Başarıyı Artıran Faktörler & $\mathbf{f}$ & Başarıyı Azaltan Faktörler & $\mathbf{f}$ \\
\hline $\begin{array}{l}\text { Öğrencilerin konuyu merak etmeleri ve } \\
\text { konuya karşı ilgili olmaları }\end{array}$ & 6 & $\begin{array}{l}\text { Öğrencilerin kavram bilgisinin yetersiz } \\
\text { olması }\end{array}$ & 3 \\
\hline $\begin{array}{l}\text { Türkiye'nin jeopolitik konumu gereği sıcak } \\
\text { çatışma bölgelerine yakın olması ve bu }\end{array}$ & 5 & $\begin{array}{l}\text { Öğrencilerin } 12 . \text { sınıfta üniversite sınavına } \\
\text { yoğunlaşması }\end{array}$ & 2 \\
\hline bölgelerin Türkiye’yi ilgilendirmesi & & Güncel konulara karşı ilgisizlik & 2 \\
\hline $\begin{array}{l}\text { Konunun anlatımında haritalardan ve } \\
\text { görsellikten yararlanılması }\end{array}$ & 3 & $\begin{array}{l}\text { Ders kitabının çok yüzeysel kalması ve } \\
\text { kalıp bilgilerden oluşması }\end{array}$ & 1 \\
\hline $\begin{array}{l}\text { Öğrencilerin politikaya karşı olumlu bakış } \\
\text { açısı }\end{array}$ & 3 & $\begin{array}{l}\text { Konunu üniversite sınavında ağırlığının } \\
\text { olmaması }\end{array}$ & 1 \\
\hline $\begin{array}{l}\text { Konunun anlatımında aktif ögrenme } \\
\text { yönteminin kullanılmasına }\end{array}$ & 3 & & \\
\hline $\begin{array}{l}\text { Çatışma bölgeleri ile ilgili haberlere yazılı } \\
\text { ve görsel medyada sıklıkla rastlamaları }\end{array}$ & 2 & & \\
\hline
\end{tabular}
şekildedir:

Öğrencilerin başarısı hakkında olumlu görüş bildiren katılımcılardan bir kısmının cevapları şu

Ö3: Bu konunun kavramlarının ögretiminin kolay olmasl, öğrencilerin konuya büyük merak duyması ve ilgili oluşu ve öğrencilerin derse katılım oranının yüksek olması. Tartışma, münazara vb. yöntemleri kolaylıkla ders anlatımında kullanilyyor.

Ö7: Gazetelerde ve televizyonlarda Türkiye'yi de yakından ilgilendiren sıcak çatışmalar ve bu bölgeler ile ilgili haberlere fazlasılla rastlanmaktadır. Ögrenciler 12. sinıf konusu olması dolaylsiyla yaş itibariyle de yavaş yavaş siyasete ilgi duyuyor bu dönemde. Bu gibi faktörler bir araya gelince başarı da tabi ki artıyor.

Ö8: Öğrenciler "sıcak çatışma bölgeleri" konusuna karşı bakış açıları çok olumlu. Özellikle güncel olaylar olması derse katılımı artırıyor. Öğrencinin derse katılımı, aktif ögrrenme yöntemlerini ders içinde kolaylıkla uygulamamı sağlamakta, bu durum da başarıyı olumlu etkilemekte.

Ö18: Sıcak çatışma bölgeleri güncel konuları kapsadığg için öğrenciler bu konudan haberdardır. Aynı zamanda Türkiye jeopolitik konumu gereği Kafkasya, Ortadoğu, Orta Asya gibi sıcak çatışma alanlarının kesişme alanında bir ülke olması, öğrencilerde merak ve motivasyonu artirlyor.

Öğrencilerin başarıları hakkında olumsuz görüş bildiren bazı katılımcıların cevapları şu şekildedir:

Ö5: Öğrencilerin kavram bilgilerinin az olmast ve konuya karşı ilgisizliği başarı oranını düşürmekte. Bu konuda ders kitabı çok yüzeysel kalmış ve kalıp bilgilerden oluşuyor. Ayrıca bu dönem de girecekleri üniversite sinavl, coğrafya dersi konu ve kazanımlarının önüne geçiyor. Ö14: Öğrencilerin dünya siyasetine karşı genel olarak ilgisi olsa da tek konsantrasyonları üniversite sınavı. Bu yüzden ögrenciler ders başarılarından ziyade sınava odaklanmış durumda. Konunun üniversite sinavında ă̆ırlı̆̆ı olmaması, öğrenci başarısını düşürüyor.

Ö20: Öğrencilerin eleştirisel düşünme, yaratıcı düşünme, problem çözme gibi zihinsel beceri düzeyleri düşük. Öğrenciler genellikle sunuş yolu ile ögretim yapılmasını istiyorlar. Ama bu konularda ögrenci merkezli eğitim yapılması başarıyı getirebilir. Güncel konulara karşı ilgisizlikleri var. 


\section{Sonuç ve Tartışma}

Siyasi öğretmen görüşlerine göre coğrafya konularında öğrencilerin genel olarak başarı düzeyleri yüksektir. Ancak öğrencilerin tarihsel süreçte Türkiye'nin jeopolitik konumu, sıcak çatışma bölgeleri konularında başarı düzeyi daha yüksek iken; Türkiye'nin çevresindeki bölgesel sorunlar, küresel ve bölgesel örgütler konusunda öğrenci başarısı daha düşüktür. Siyasi coğrafya konularında öğrenci başarılarının yüksek olmasında etkili olan faktörleri öğretmen görüşlerine göre şu şekilde sıralayabiliriz:

a- Türkiye'yi doğrudan veya dolaylı olarak ilgilendiren bölgesel sorunların bulunması, Türkiye'nin jeopolitik önemi ve günümüz çatışma bölgeleriyle Türkiye'nin sınır olması öğrencilerin siyasi coğrafya konularına karşı daha duyarlı olmasına ve başarılarının artmasına neden olmaktadır. Özellikle dünyayı ilgilendiren pek çok olayın ülkemizin yakınındaki coğrafyalarda gerçekleşmesi öğrencilerin büyük bir kısmının siyasi coğrafya konularına ilgili olmasında etkilidir. Bu durum yakından uzağa ilkesinin öğretimde etkisi bağlamında düşünülebilir. Pek çok araştırmacı bu duruma dikkat çekmiştir (Küçükahmet, 2000).

b- Siyasi coğrafya konularının günlük yaşamla ilgili olması, yazılı ve görsel medyada bu konuların sıklıkla yer alması yani güncel konular olması başarıyı artıran diğer bir faktördür. Bu faktör güncellik yani aktüalite ilkesinin eğitim-öğretim faaliyetlerindeki olumlu etkisi ile ilişkilidir. "Güncellik ilkesi gereği, işlenen konuların günlük hayata yansımış yönleri ele alınmalıdır. Bu ilke, öğrencilerin yaşadıkları hayatın gerçekleriyle karşı karşıya gelmelerini ve yakın çevre, yurt ve dünya olaylarına karşı ilgi duymalarını sağlamak için ders konularıyla güncel olay ve sorunlar arasında ilişki kurularak dersin işlenmesini öngörmektedir" (Büyükkaragöz ve Çivi, 1997: 59). Güngördü (2002) de "verilen öğretim, günlük basın ve yayın organlarını izleyen, bu yayınlardaki görüş ve düşünceleri eleştirebilen, bireyleri yetiştirecek şekilde düzenlenmelidir" diyerek güncellik ilkesinin siyasi coğrafya konularının öğretiminde önemine dikkat çekmiştir. Siyasi coğrafya konuları güncellik ve yaşanırlılık ilkesinin uygulanabilmesine çok uygundur.

c- Aktif öğrenme yöntem ve tekniklerinin, siyasi coğrafya konularının öğretiminde kullanılması başarı düzeyini artırmaktadır. Aktif öğrenme, öğrenenin öğrenme sürecinin sorumluluğunu taşıdığı, öğrenene öğrenme sürecinin çeşitli yönleri ile ilgili karar alma ve öz düzenleme yapma firsatlarının verildiği ve karmaşı öğretimsel işlerle öğrenenin öğrenme sırasında zihinsel yeteneklerini kullanmaya zorlandığı bir öğrenme sürecidir (Açıkgöz, 2014: 17). Özellikle siyasi coğrafya konularında soru-cevap, beyin firtınası, tartışma çok fazla kullanılan aktif öğrenme yöntem ve teknikleri olarak karşımıza çıkmaktadır. $\mathrm{Bu}$ durum öğrencilerin derse aktif katılımını sağlamakta ve öğrenci başarısını artırmaktadır.

d- Siyasi coğrafya konularında öğrencilerin başarı düzeyinin yüksek olmasında bu konuların tarih dersinde de görülüyor olması, özellikle de 12. sınıf dersi olan Çağdaş Türk ve Dünya Tarihi dersinin etkisi büyüktür. Bu durum öğretimde disiplinler arası yaklaşımın önemini ortaya koymaktadır. Yıldırım (1996), disiplinlerarası öğretimi, farklı disiplinlere ait bilgi ve becerileri anlamlı bir biçimde bir araya getirme ve kullanma yönünde etkili bir strateji olduğunu belirtmektedir.

e- Başarı üzerinde etkili olan faktörlerden bir tanesi de üniversite sınavlarıdır. Öğrenciler genellikle üniversite sınavında soru gelme ihtimali fazla olan siyasi coğrafya konularında daha yüksek başarı oranı göstermektedir. Geçmiş yıllarda soru gelmemiş veya soru gelme ihtimali düşük konularda başarı oranı düşmektedir. Bu da halen liselerde özellikle de 12. sınıfta müfredattan ziyade üniversite sınavının önem arz ettiğini göstermektedir.

f- Siyasi coğrafya konuların öğretiminde ders içerisinde Google Earth programından faydalanmak öğrenci başarısını artırmaktadır. "Yeryüzüne ait uydu görüntülerinin internetten gözlemlenmesini sağlayan Google Earth, detayları konum bilgileri ile sunduğu için mekânsal sorgulama 
ve analizlere imkân vermektedir" (Demirci ve Karaburun, 2011:101). Google Earth programı; jeopolitik konum, coğrafi konum, çatışma bölgeleri, küresel örgütler gibi konusu temel lokasyon becerilerini içeren bu kavramların öğretimini kolaylaştırmakta ve bu durum başarıyı artırmaktadır.

Bazı siyasi coğrafya konularında öğrenci başarısını düşüren faktörler ise şu şekilde sıralanabilir:

a- Bazı öğrencilerin siyasete karşı ilgisiz oluşu

b- Harita bilgilerinin yetersiz olmas 1

c- Ülkeleri tanımamaları ve önbilgi eksikliği

d- Eleştirisel ve yaratıcı düşünme becerilerin az olması

e- İlgi alanlarının magazin, futbol, oyun vb. etkinlikler olması

f- Aktif öğrenme yöntemleriyle ders işlenmesinden çok hoşnut olmaması.

\section{5. Öneriler}

a- Siyasi coğrafya konu ve kavramlarının tarih dersinde de görülüyor olması bu iki disiplin arasında disiplinlerarası yaklaşımın önemini ortaya çıkarmaktadır. Tarih ve coğrafya öğretmenlerinin siyasi coğrafya kavramlarının öğretiminde iş birliği içerisinde olmaları önerilmektedir.

b- Coğrafya ders kitaplarında özellikle de siyasi coğrafya konularında dilsiz harita etkinliklerinin sayısı artırılmalıdır. Öğretmenler konulara uygun harita ve dilsiz harita etkinlikleri hazırlamalı ve bunları uygulamalıdır. Özellikle Google Earth, coğrafi bilgi sistemleri gibi uygulamaları ders içinde kullanılabilir.

c- Siyasi coğrafya konularının güncel konular olması nedeniyle yazılı ve görsel medyada sıklıkla yer bulmaktadır. Gazete, dergi, internet vb. güncel kaynaklardan elde edilen siyasi coğrafya haberleri ders içerisinde kullanılabilir. $\mathrm{Bu}$ durum, siyasi coğrafya konularının günlük yaşamla ilişkilendirilmesine ve güncel olayların sınıf ortamına taşınması dolayısıyla öğrencilerin başarılarının daha da yükselmesine yol açabilir.

d- Coğrafya öğretmenlerinin, etkililiği çeşitli araştırmalar ile ortaya konulmuş olan aktif öğretim yöntemlerini, siyasi coğrafya konularında kullanımı ile ilgili hem bilgi edinmesi hem de uygulama konusunda gerekli bilgi ve deneyimleri kazanmasını sağlayabilecek hizmet içi eğitimler düzenlenebilir.

e- Üniversite sınavlarında coğrafya dersinden gelen soru sayısının artırılması, siyasi coğrafya konularından da öğrencilere soru sorulması gerekmektedir. Bu durum siyasi coğrafyanın önemini ve ögrencilerin bu konulara karşı ilgisini artırabilir.

f- Ülkemizde siyasi coğrafya üzerine son yıllarda yapılan çalışma sayısında önemli artış bir

Artı̧̧ olsa da siyasi coğrafya öğretimi üzerinde yapılan araştırma sayısı son derece azdır. Ülkemizde benzer araştırmaların yapılmasına önem verilebilir.

\section{KAYNAKÇA}

Açıkgöz, K. Ü. (2008). Aktif öğrenme. İzmir: Biliş Gelişimin Coşkusu.

Akengin, H. (2013). Siyasi coğrafya insan ve mekân yönetimi. Ankara: Pegem Akademi.

Atalay, İ. (2001). Genel fiziki coğrafya. İzmir: Ege Üniversitesi Basımevi.

Atalay, İ. (2004). Türkiye coğrafyası ve jeopolitiği. İzmir: Meta Basım.

Baltac1, A. (2018). Nitel araştırmalarda örneklem yöntemleri ve örnek hacmi sorunsalı üzerine kavramsal bir inceleme. Bitlis Eren Üniversitesi Sosyal Bilimler Enstitüsü Dergisi, 7(1), 231274. 
Büyükkaragöz, S. ve Çivi, C. (1997), Genel Öğretim Metotları. Yedinci Baskı. İstanbul: Öz Eğitim Yayınları.

Büyüköztürk, Ş., Çakmak, E. K., Akgün, Ö. E., Karadeniz, Ş. ve Demirel, F. (2013). Bilimsel araştırma yöntemleri. Ankara: Pegem Yayınevi.

Creswell, J.W. (2007). Qualitative inquiry and research desing: Choosing among five approaches. (2nd Press). SAGE Publications.

Demirci, A. ve Karaburun, A. (2011). CBS, CPS ve Google Earth teknolojilerinin coğrafya derslerinde kullanımı. Marmara Coğrafya Dergisi, 24, 99-123. Erişim adresi: https://dergipark.org.tr/download/article-file/3255.

Demirci, A. (2005). Küreselleşen dünyamızda coğrafyanın siyasal gücü ve Türkiye ölçeğindeki rolü. Marmara Coğrafya Dergisi, 12, 1-16. Erişim adresi: http://dspace.marmara.edu.tr/handle/11424/2485.

Deniz, T. (2010). Buluş yoluyla öğretim yaklaşımının siyasi coğrafya konularının ögretiminde öğrenci başarısına etkisi (Yayınlanmamış doktora tezi). Erişim adresi: http://www.acikarsiv.gazi.edu.tr/File.php?Doc_ID=4209\&ses=

Doğanay, H. (1993). Coğrafyaya giriş 1. Ankara: Gazi Büro Kitabevi.

Güngördü, E. (2002). Coğrafyada ögrretim yöntemleri ilkeler ve uygulamalar (1. Basım). Ankara: Nobel Yayın Dağıtım.

İlhan, S. (1993). Türkiye'nin ve Türk Dünyası'nın jeopolitiği. Türk Kültürü Araştırma Enstitüsü Yayınları.

Koçak, K. (1993). İlköğretim kurumlarında öğrenci başarısının değerlendirilmesi. Çağdaş Eğitim Dergisi, 189, 18-25. Ankara: Tekışık Matbaası.

Küçükahmet, L. (2000). Öğretimde Planlama ve Değerlendirme. Ankara: Nobel Yayın Dağıtım

Millî Eğitim Bakanlığı. (2018). Coğrafya dersi öğretimi programı (9., 10., 11. ve 12. sınıflar). Erişim adresi: http://mufredat.meb.gov.tr/Dosyalar/2018120203724482Cografya\%20dop\%20pdf.pdf.

Özay, E. (2003). Ortaöğretim coğrafya eğitimi ve öğretiminde gezi-gözlem metodunun öğrenci başarısı üzerine etkisi ve diğer öğretim metodlarıyla karşılaştırılması (Yayınlanmamış yükssek lisans tezi). Marmara Üniversitesi Eğitim Bilimleri Enstitüsü. İstanbul.

Özey, R. (2007). Dünya ve Türkiye ölçeğinde siyasi coğrafya. İstanbul: Aktif Yayınevi.

Özgen, N. (2010). Bilim olarak coğrafya ve evrimsel paradigmaları. Ege Coğrafya Dergisi, 19 (2), 126, Erişim adresi: https://dergipark.org.tr/download/article-file/56753.

Özgen, N. (2016). Nitel araştırmalarda verilerin toplanması ve analizi. N. Özgen (Ed.), Beşerî coğrafyada araştırma yöntemleri ve teknikleri içinde (s. 158-196), Ankara: Pegem Akademi.

Sarıer, Y. (2016). Türkiye'de öğrencilerin akademik başarısını etkileyen faktörler: bir meta analiz çalışması. Hacettepe Üniversitesi Ĕgitim Fakültesi Dergisi, 31(3), 609-627. Erişim adresi: http://efdergi.hacettepe.edu.tr/upload/files/3080basariiietkileienfaktorler-meta-analiz.pdf.

Tozo, A.T. (2011). Türkiye'nin jeopolitiği ve bölgesel sorunları konusunun probleme dayalı ögrenme yöntemi ile ögrenci başarı ve tutumuna etkisinin değerlendirilmesi (Yayınlanmamış yüksek lisans tezi). Erişim Adresi:http://www.acikarsiv.gazi.edu.tr/File.php?Doc_ID=7152.

Turoğlu, H. (2003). Coğrafyacı ve coğrafya eğitimi. Türk Coğrafya Kurumu Coğrafya Kurultayl, 9-12 Temmuz 2002, Bildiriler İçinde (52-58). Ankara: Gazi Kitabevi. 
Tümertekin, E. ve Özgüç, N. (1998). Beşerî coğrafya insan, kültür, mekân. İstanbul: Çantay Kitapevi.

Yıldırım, A. ve Şimşek, H. (2013). Sosyal bilimlerde nitel araştırma yöntemleri. Ankara: Seçkin Yayınc1lik.

Yıldırım, A. (1996). Disiplinlerarası ögretim kavramı ve programlar açısından doğurduğu sonuçlar. Hacettepe Üniversitesi Ë̆itim Fakültesi Dergisi (12) 89-94, Erişim adresi:

http://www.efdergi.hacettepe.edu.tr/yonetim/icerik/makaleler/1270-published.pdf. 